DOI: 10.22616/REEP.2020.005

\title{
Students' Opinion on the Quality Assurance of a Study Process: Case Study at Daugavpils University, Latvia
}

\author{
Jel̦ena Davidova ${ }^{1}$ Dr.paed.; Irēna Kokina ${ }^{2}$ Dr.psych. \\ Daugavpils University, Latvia \\ jelena.davidova@du.lvi ; irena.kokina@du.lv²
}

\begin{abstract}
It is obvious that in recent years the system of higher education quality assurance has undergone several essential changes: a greater emphasis is being laid on the qualification framework, on student-centred learning and study results; also there is a change in the attitude from quality assurance towards the development of the teaching staff. One of the characteristics of higher education is the extent the higher education is based on active students' participation in the assessment of the study process. The aim of the study is to explore students' opinions about the process of study quality assurance at the Daugavpils University (further - DU), Latvia. The participants of this study were 60 students from 12 master and doctoral study programs at DU. The analysis of structured interviews with the students made it possible to identify the typical characteristic features of DU internal quality assessment. The research showed that students assess highly lecturers' personal qualities (attitude to their profession, personal interest in students' success, empathy, striving for cooperation) and their professional qualities (knowledge of the subject, didactic and communicative competence, and ability to get the feedback from students as well). To promote the cooperation between the students and the academic staff of DU, it is useful to practice trans-disciplinary out-of-study forms. Summer schools for students studying in master and doctoral programs encourage students to think about the future of civilization, about a sustainable and unsustainable behaviour on a local and global scale, goals of a sustainable development and awareness about them, and also about the role of a qualitative education content and study environment for achieving these goals. The use of international summer schools, academic discussions and creative work-shops contribute to a deeper understanding of the study content, of topicalities in global education and possibilities of synergetic thinking in cooperation between students and lecturers.
\end{abstract}

Keywords: study process quality assurance, out-of-study forms in a higher education institution.

\section{Introduction}

A further quality assurance (further - QA) of a higher education institution (further - HEI) relates to the compliance of aims, content, practice and results of education with the future of new generations at solving the problems of the new millennium. The increase in the HEI added value greatly depends on the improvement of the internal processes, while the creation of value is mainly based on the adequacy of aims and satisfaction of people who are concerned with the growth of education services (Davidova, Kokina, 2018, 2019).

Quality management is a decisive factor in a sustainable development of HEI. The goal of the Bologna Process is to develop the area of Europe's higher education and make European higher education competitive, transparent and multiform by assuring a qualitative higher education which will create conditions for a sustainable social-economic development (The Bologna Declaration, 1999). In order to develop quality assurance in European higher education area following the Bologna Declaration in 2000 the European Association for Quality Assurance in Higher Education (ENQA, 2019) was created as a European network for quality assurance in higher education.

The main principles of European standards and guidelines for higher education are:

- good quality of higher education where the interests of students, employers and society are taken into consideration;

- institutional autonomy;

- proper external quality assurance for the goals of the institution (Standards and Guidelines..., 2015).

According to the ESG revised version adopted on May 15-16, 2015, at the Summit of European Ministers in Erevan (Standards and Guidelines..., 2015), many aspects of quality assurance are being 
dealt with, for instance, such as a quality of academic standards, adequacy of assessment, involvement of those concerned into the management and the reliability of internal practice. This document stresses the fact that higher education institutions must have QA policy oriented towards:

- development of QA system;

- responsibility of structural units and HEI management, staff and students for QA;

- academic honesty and freedom;

- intolerance to academic deceit;

- struggle against lack of tolerance and discrimination of students and the staff;

- involvement of external interested parties in QA.

In 2016, at the $25^{\text {th }}$ conference "Management and Qualitative Education" the ministers of education from ES member states came to an agreement that education quality is closely related to four interrelated aims:

- training for a sustainable employment;

- getting ready for life as active citizens in a democratic society;

- personal development;

- to develop and maintain a comprehensive, progressive knowledge base via teaching, learning and studying (Council of Europe, 2016).

The external and internal environment of HEI-s constantly changes. Over the time, the role of students, as those concerned internally, has been different. In between 1970 and 1990, students could be seen more frequently as members of academic community in the leading structures of HEI (Student Göteborg Convention, 2001). HEIs compete to attract and maintain a highly qualified academic environment (Baruch, 2006). The young generation (called Gen Y) is highly skilled people that place high value on career development and would like to work for organizations that will provide them with career development opportunities (Mayer, 2006; KASASA, 2019). The environment around us has an impact on students' consciousness and sub-consciousness. The quality of a study process determines the way of their thinking, habits and personality on the whole.

A comprehensive QA system ought to verify the diverse quality concepts by making use of three interrelated areas:

- quality of available human and material resources;

- quality of management and a study process;

- quality of outcomes (Frazer, 1994; Westerheijden, Kohoutek, 2013; IQM-HE, 2016; Ganseuer, Pistor, 2017; Martin, Parikh, 2017).

In HEI, the academic factors identify an important aspect of education quality. A. Lizzio with colleagues (Lizzio, Wilson, Simons, 2010) have established that the understanding about the HEI study environment enhances the academic outcome, while the previous academic achievements do not influence it.

The majority of studies on the system of quality management in industry and education underline factors that promote the development of this system, for example, such as obligations of a higher-level management, involvement of employees and a continuous development (Curry, Kadasah, 2002; Montes, Jover, Fernández, 2003). Research on the quality management in higher education emphasizes the especial importance of QA effectiveness (Welsh, Dey, 2002; Wiklund et al., 2003; Logermann, 2014; Tomsikova, Slavik, 2014; Roskosa, Stukalina, 2018; Nemejc, Smekalova, Kriz, 2019).

Recent five years testify to essential changes in the QA system of HEI:

- a greater emphasis is put on a qualification framework, student-centred studies and learning outcomes;

- change in the attitude from quality assurance towards the development of a teaching staff;

- greater attention is given to the regulations on the financing for studies and educational activities, adequate and easily accessible study resources and the support for students.

At the same time, these tendencies focus on the quality of students' services, but quality in its turn unavoidably requires students' involvement on an institutional, national and European level. Students, as an important internal HEI group of those concerned, are active partners with a shared responsibility for their own learning and achievements. Actually, one of the characteristics of higher education is the 
extent to which it is based on students' active participation in the assessment of a study process and on students' sense of belonging to the higher education institution. The degree of their satisfaction is an essential indicator of HEI reputation.

A good HEI has to be aware of students' expectations (prospective development aims) in order to work out plans for its QA policy and strategic development, as well as to create a reasonable and humane system of education management. Despite the fact that students' involvement into processes of internal quality assurance of HEI is an essential factor for achieving the Bologna goals as to the quality, the studies on the issue of students' integration into the procedures of internal quality assurance are very few and fragmentary (Kohoutek, Land, Owen, 2013). Besides, little is known about students' actual situation or influence on processes of internal quality assurance to achieve a high study quality level. To assess the current situation concerning the procedures of internal quality according to the Bologna Declaration (The Bologna Declaration, 1999), this research is oriented towards studying students' position on the process of study quality assurance at Daugavpils University.

The aim of the study is to explore the DU students' opinions about the process of study quality assurance at Daugavpils University.

\section{Methodology}

Studies based on a qualitative methodology allow us to more objectively identify the QA similarities, differences and ideas about the quality of a study process and students' satisfaction with its course. The research process for this case study involved the use of structured interviews aimed at collecting data about students' position in the context of quality assurance of a study process at Daugavpils University. The data obtained during interviews of this qualitative research were analysed according to the R. Tesch (1990) principles.

A total of 60 informants (students from 12 master and doctoral study programs at DU) participated in the interviews individually. Each interview was non-structured and about 30 to $40 \mathrm{~min}$ long. The interview data were collected, transcribed and analysed according to regular qualitative coding principles (Dey, 1993). Responses from each participant were analysed in detail and in isolation from those of other participants; there were several approaches to the analysis of these responses and the key words were identified.

The key words were classified into broader categories that might be refined and challenged until the key words classified reasonably. The major open-ended questions in the interviews were about study process quality: competences and personal qualities of academic staff, study program's content, evaluation requirements, as well as about students' participation in study quality assessment. A qualitative data analysis was achieved by identifying topics in the frames of research object in the collected research data, which were synthesized and generalized.

\section{Results and Discussion}

The analysis of interviews with the students enabled us to identify the typical characteristic features of DU study quality assessment which are shown in Table 1.

On the whole, students assess competences of DU lecturers in their respective areas and their favourable attitude to students as high. However, to students' mind, there could be more practical classes in some subjects. As regards the requirements for assessing learning outcomes, students are satisfied with the fact that the assessment requirements and criteria are clear to them and lecturers are objective when assessing their knowledge, skills and competences.

When students evaluate their cooperation with lecturers, they greatly appreciate academic staff's readiness to motivate, help and support students: this encourages them to develop themselves. In regard to students' possibility to influence a study process as well as content quality all the informants are positive: lecturers are obliging and work with students outside their class-time, if the students need it; in case any problems arise, they are resolved in cooperation with a program director. 
Students state that they are active participants in assessing the study process and take part in surveys, work in study program councils and on faculty Boards or openly and constructively communicate with the academic and administrative staff in this context.

Table 1

DU students' opinion about the characteristic features of quality assessment $(\mathrm{N}=60)$

\begin{tabular}{|c|c|}
\hline $\begin{array}{c}\text { Study quality } \\
\text { parameters }\end{array}$ & Examples of students' statements \\
\hline $\begin{array}{l}\text { Lecturers' } \\
\text { competences in } \\
\text { the respective } \\
\text { area }\end{array}$ & $\begin{array}{l}\text { - Study course content complies with the requirements [...] and the program title...; } \\
\text { - Lecture materials are very well-considered [...] and structured; } \\
\text { - Lecturers at DU are very professional. }\end{array}$ \\
\hline $\begin{array}{l}\text { Assessment of } \\
\text { the study results } \\
\text { to be acquired }\end{array}$ & $\begin{array}{l}\text { - We are always informed about assessment requirements; } \\
\text { - Assessment requirements are clear, [...] and on a high level; } \\
\text { - Assessment requirements are explained at the beginning of a study course; } \\
\text { - Lecturers give objective assessment of study results...; } \\
\text { - ...study results are assessed according to specific criteria [...] which are explained by } \\
\quad \text { the lectures at the beginning of the semester. }\end{array}$ \\
\hline $\begin{array}{l}\text { Cooperation } \\
\text { with lecturers }\end{array}$ & $\begin{array}{l}\text { - Regular cooperation...on both lecturer's and my own initiative...; } \\
\text { - Lecturers' attitude is always motivating, supporting and patient; } \\
\text { - } \quad \text {...in case of need, a lecturer gives assistance and support all the time...; } \\
\text { - } \quad \text { Cooperation is regular, on the initiative of both parties; } \\
\text { - } \quad \text {... cooperation-oriented [...] study process encourages and motivates to perfect } \\
\quad \text { oneself [...] as well as support the other students and help them in case of need. }\end{array}$ \\
\hline $\begin{array}{l}\text { Students' } \\
\text { possibility to } \\
\text { influence the } \\
\text { quality of study } \\
\text { process and } \\
\text { content }\end{array}$ & $\begin{array}{l}\text { - If we wish, we can approach the lecturer about an in-depth acquisition or research of } \\
\text { a theme [...], lecturers are obliging and highly qualified in their respective fields; } \\
\text { - Lecturers take interest in what is urgent for us at this moment, [...] and are ready to } \\
\text { organize additional classes for an in-depth study of the material; } \\
\text { - We inform lecturers or a study program director about various problems arising at } \\
\text { acquiring one or another study course [...], as well as about our satisfaction with it. } \\
\text { [...] the academic staff always tries to help us to resolve the problem; } \\
\text { - There is constantly a good dialogue with lecturers.... }\end{array}$ \\
\hline $\begin{array}{l}\text { Students' } \\
\text { participation in } \\
\text { study process } \\
\text { assessment }\end{array}$ & $\begin{array}{l}\text { - We regularly fill in questionnaires containing questions about different aspects of a } \\
\text { study process; } \\
\text { - Students are involved in study program councils and can make their proposals } \\
\text { concerning the improvement of a study process...; } \\
\text { - ...we actively communicate with lecturers and a program director about various issues } \\
\text { of a study process. }\end{array}$ \\
\hline
\end{tabular}

This research showed that lecturers' personal qualities (attitude to their profession, taking interest in students' achievements, empathy, striving for cooperation) as well as their professional qualities (knowledge of the subject, didactic and communicative competence, and also the ability to get feedback from students) are very important for students. In this aspect, the data obtained in our research are closely analogous to the results of the research done by S. Arnon and N. Reichel, who established that such lecturers' qualities as general knowledge, orientation to a specific social mission are considered by students as less important (Arnon, Reichel, 2007).

What concerns the diversity of out-of-study forms, we can say that for several years already DU has been practicing summer schools for students in master and doctoral programs. This study process form encourages students to think about the future of civilization, sustainable and unsustainable behaviour on a global and local scale, about aims of a sustainable development and awareness about them, as well as about the role of a qualitative education content and study environment for achieving these aims.

During group discussions, the summer school participants managed to identify the possible ways for their cooperation, some complex education problems and opportunities for engaging in deeper studies of these problems (for example, challenges in higher education, higher education quality, innovations, 
research paradigms, inter-disciplines, and other themes). Students also take part in creative work-shops and academic discussions.

As to the questions on the influence of summer schools, students emphasize the valuable experience gained by their participation in the discussions organized by summer schools (see Table 2).

Table 2

\section{DU students' opinion about the influence of summer schools in the context of assuring study} quality $(\mathrm{N}=60)$

\begin{tabular}{|c|c|}
\hline $\begin{array}{l}\text { Parameters of } \\
\text { summer school } \\
\text { influence }\end{array}$ & Examples of students' statements \\
\hline $\begin{array}{l}\text { Improvement of } \\
\text { knowledge and } \\
\text { competences }\end{array}$ & $\begin{array}{l}\text {-..help to more thoroughly understand the role of education both on a global and } \\
\text { local scale; } \\
\text { - ...help to have a better grasp of sustainable and unsustainable activities...; } \\
\text { - ...contribute to producing new ideas.... }\end{array}$ \\
\hline $\begin{array}{l}\text { Opportunities for } \\
\text { cooperation and } \\
\text { self-development }\end{array}$ & $\begin{array}{l}\text { - Two heads are better than one; } \\
\text { - Live and learn, feel inspired and cooperate! } \\
\text { - Cooperation leads towards the goal set! } \\
\text { - The skill of cooperating productively is one of the basic elements of sustainability! } \\
\text { - ...promote the development of skills of how to cooperate productively and be } \\
\text { synergetic; } \\
\text { - ..ensure cooperation between lecturers and students based on the principles of } \\
\text { freedom and partnership; } \\
\text { - ...promote setting specific aims for developing oneself professionally; } \\
\text { - ...help to reflexively assess experience gained previously and outline broader } \\
\text { opportunities for the development in future. }\end{array}$ \\
\hline
\end{tabular}

At summarizing the opinions expressed by the majority of students about the usefulness of summer schools, the key words used in the statements of summer school participants are as follows: sense of strength in the community, process of creation, very good feelings, a lot of new ideas, exchange of contacts and experience, diversity in generating ideas, positive mutual dependence, and energy for the whole year. Students especially appreciate the opportunities for cooperation and self-development provided by summer schools.

\section{Conclusions}

- Study process quality is one of the factors for the effectiveness of HEI internal quality assurance. A regular study process assessment helps to maintain the internal quality of HEI as well as to better understand changes and possible tendencies of the current period, responding in case of need to the established changes in due time. Students' involvement in the processes of HEI internal quality assurance guarantees an adequate coordination between HEI management processes and perspective needs of society. The research data show that the personal qualities and professional qualification of the teaching staff are one of the most important factors that influence the perception of education quality.

- A higher education institution has to provide students with better conditions for studies, with adequate activities for acquiring the study content, as well as to promote the environment for self-development. To encourage the cooperation between DU academic staff and students, it is advisable to practice trans-disciplinary out-of-study forms (for example, international summer schools, academic discussions, and creative work shops). Work in summer schools a) helps to deeper understand the study content, global topicalities in higher education and also provide opportunities for synergetic thinking in cooperation between lecturers and students; b) gives creative impulses for the nearest perspective; c) creates a platform for generating new ideas; $d$ ) provides an opportunity for identifying oneself as a researcher in the area of interdisciplinary and trans-disciplinary problem studies. 


\section{Bibliography}

1. Arnon S., Reichel N. (2007). Who is the Ideal Teacher? Am I? Similarity and Difference in Perception of Students of Education Regarding the Qualities of a Good Teacher and of Their Own Qualities as Teachers. Teachers and Teaching: Theory and practice, 13(5), 441-464. doi: 10.1080/13540600701561653

2. Baruch Y. (2006). Career Development in Organizations and Beyond: Balancing Traditional and Contemporary Viewpoints. Human Resource Management Review, 16(2), 125-138. doi: 10.1016/j.hrmr.2006.03.002

3. Council of Europe. (2016). 25th Session of the Council of Europe Standing Conference of Ministers of Education. Retrieved from http://www.coe.int/t/dg4/education/standingconf/Default_en.asp

4. Curry A., Kadasah N. (2002). Focusing on Key Elements of TQM: Evaluation for Sustainability. The TQM Magazine, 14(4), 207-216. doi: 10.1108/09544780210429816

5. Davidova J., Kokina I. (2018). Paradigms, Approaches and Principals of Knowledge Management. In V. Dislere (Ed.), The Proceedings of the International Scientific Conference Rural Environment. Education. Personality (REEP), 11. Jelgava: Latvia University of Life Sciences and Technologies, 58-65. doi: 10.22616/REEP.2018.006

6. Davidova J., Kokina I. (2019). Study Environment in the Context of HEI Study Quality Assurance: Case study at Daugavpils University (Latvia). In J. Domenech, P. Merello, E. de la Poza, D. Blazquez, R. Peña-Ortiz (Eds.), Proceedings of the $5^{\text {th }}$ International Conference on Higher Education Advanced (HEAD'19). Valencia: Universitat Politècnica de València, València, 1305-1312. doi: 10.4995/HEAd19.2019.9047

7. Dey I. (1993). Qualitative Data Analysis: A User-friendly Guide for Social Scientists. London: Routledge. Retrieved from http://fsnnetwork.org/sites/default/files/qualitative_data_analysis.pdf

8. ENQA. (2019). European Association for Quality Assurance in Higher Education. Retrieved from https://enqa.eu/index.php/about-enqa/

9. Frazer M. (1994). Quality in Higher Education: An International Perspectives. In D. Green (Ed.), What is Quality Higher Education. UK: SRHE and Open University Press, 101-111. Retrieved from https://files.eric.ed.gov/fulltext/ED415723.pdf

10. Ganseuer Chr., Pistor P. (2017). From Tools to an Internal Quality Assurance System University of Duisburg-Essen, Germany. Paris: International Institute for Educational Planning. Retrieved from https://unesdoc.unesco.org/ark:/48223/pf0000249502

11. IQM-HE. (2016). Internal Quality Management in Competence-Based Higher Education. Retrieved from https://iqmhe.wordpress.com/

12. KASASA. (2019). Boomers, Gen $X$, Gen $Y$, and Gen $Z$ Explained. Retrieved from https://www.kasasa.com/articles/generations/gen-X-gen-y-gen-Z

13. Kohoutek J., Land R., Owen C. (2013). Identifying Barriers in Promoting the European Standards and Guidelines for Quality Assurance at Institutional Level (IBAR): Final synthesis report IBAR Project. Retrieved from

https://www.academia.edu/30102971/Identifying_barriers_in_promoting_the_European_Standar ds_and_Guidelines_for_Quality_Assurance_at_institutional_level_IBAR_

14. Lizzio A., Wilson K., Simons R. (2010). University Students' Perceptions of the Learning Environment and Academic Outcomes: Implications for Theory and Practice. Studies in Higher Education, 27(1), 27-52. doi: 10.1080/03075070120099359

15. Logermann F. (2014). Students as Stakeholders in the Policy Context of the European Standards and Guidelines for Quality Assurance in Higher Education Institutions: A comparative case study of a Dutch and German higher education institution. (Master Thesis. Universiteit Twente). Retrieved from https://essay.utwente.n1/65543/

16. Martin M., Parikh S. (2017). Quality Management in Higher Education: Developments and Drivers: Results from an International Survey. Paris: International Institute for Educational Planning. Retrieved from https://unesdoc.unesco.org/ark:/48223/pf0000260226

17. Mayer J.D. (2006). Personality: A Systems Approach. New York: Pearson. 
18. Montes J.L., Jover A.V., Fernández M.M. (2003). Factors Affecting the Relationship between Total Quality Management and Organizational Performance. International Journal of Quality \& Reliability Management, 20(2), 189-209. doi: 10.1108/02656710310456617

19. Nemejc K., Smekalova 1., Kriz E. (2019). A Reflection of the Quality of Education in the Use of Teaching Aids and the Importance of Lifelong Learning. In V. Dislere (Ed.), The Proceedings of the International Scientific Conference Rural Environment. Education. Personality (REEP), 12. Jelgava: Latvia University of Life Sciences and Technologies, 94-103. doi: 10.22616/REEP.2019.012

20. Roskosa A., Stukalina Y. (2018). Management of a Study Programme in the Context of Quality Assurance in Higher Education. In V. Dislere (Ed.), The Proceedings of the International Scientific Conference Rural Environment. Education. Personality (REEP), 11. Jelgava: Latvia University of Life Sciences and Technologies, 118-127. doi: 10.22616/REEP.2018.014

21. Standards and Guidelines for Quality Assurance in the European Higher Education Area (ESG). (2015). Brussels, Belgium: EURASHE Retrieved from https://enqa.eu/wpcontent/uploads/2015/11/ESG_2015.pdf

22. Student Göteborg Convention. (2001). European Students' Information Bureau. Gothenburg. Retrieved from http://www.ehea.info/cid102734/student-goteborg-convention-march-2001.html

23. Tesch R. (1990). Qualitative Research: Analysis Types and Software Tools. New York: Falmer.

24. The Bologna Declaration. (1999). Joint Declaration of the European Ministers of Education. Retrieved from https://www.eurashe.eu/library/modernising-phe/Bologna_1999_BolognaDeclaration.pdf

25. Tomsikova K., Slavik M. (2014). Evaluation of University Education and Its Indicators. In V. Dislere (Ed.), The Proceedings of the International Scientific Conference Rural Environment. Education. Personality (REEP), 7. Jelgava: Latvia University of Life Sciences and Technologies, 131-138. Retrieved from https://lufb.llu.lv/conference/REEP/2014/Latvia-Univ-Agricult-REEP2014proceedings-131-138.pdf

26. Welsh J., Dey S. (2002). Quality Measurement and Quality Assurance in Higher Education. Quality Assurance in Education, 10(1), 17-25. doi: 10.1108/09684880210416076

27. Westerheijden D.F., Kohoutek J. (2013). Analysing the implementation of the European Standards and Guidelines for Quality Assurance at institutional level: Outcomes of the IBAR project. In D. Derricott, H. Kekäläinen, M. Kelo, R.S. Kristensen, T. Loukkola， B. Michalk，F.G. Palomares, N. Ryan, B. Stensaker (Eds.), Working Together to Take Quality Forward. European Quality Assurance Forum, 8. Sweden: University of Gothenburg, 6-12. Retrieved from https://enqa.eu/indirme/papers-andreports/occasional-papers/EUA_EQAF_Publication_web-1.pdf

28. Wiklund H., Klefsjo B., Wiklund P.S., Edvardsson B. (2003). Innovation and TQM in Swedish Higher Education Institutions - Possibilities and Pitfalls. The TQM Magazine, 15(2), 99-107. doi: 10.1108/09544780310461116 